\title{
Vegetation analysis along the altitudinal gradient of Mt. Ilong, Halcon Range, Mindoro Island, Philippines
}

\author{
ELAINE LOREEN C. VILLANUEVA ${ }^{1, \boldsymbol{\nu}}$, INOCENCIO E. BUOT, JR. ${ }^{1,2,3}$ \\ ${ }^{1}$ School of Environmental Science and Management, University of the Philippines Los Baños. College, Laguna 4031, Philippines. Tel.: +63-49-536 2836, \\ remail: ecvillanueva4@up.edu.ph \\ ${ }^{2}$ Institute of Biological Sciences, College of Arts and Sciences, University of the Philippines Los Baños. College, Laguna 4031, Philippines \\ ${ }^{3}$ Faculty of Management and Development Studies, University of the Philippines Los Baños. College, Laguna 4031, Philippines
}

Manuscript received: 8 May 2018. Revision accepted: 3 November 2018

\begin{abstract}
Villanueva ELC, Buot, JrIE. 2018. Vegetation analysis along the altitudinal gradient of Mt. Ilong, Halcon Range, Mindoro Island, Philippines. Biodiversitas 19: 2163-2174. The vegetation of Halcon Range is diverse, unique, and culturally important; however, there is a very limited information on its altitudinal distribution and structure, leading to the formation of land uses that trigger problem in sustainable management decisions for the mountain. This study analyzed the vegetation in land use types distribution along the altitudinal gradient of Mt. Ilong, Halcon Range, Mindoro, Philippines. Fourteen plots of 10 x 10m were established along the slope from $100 \mathrm{~m}-1400 \mathrm{~m}$ elevation. The tree species that were sampled from the plots were subjected to classification and ordination analyses. The dendrogram showed three distinct vegetation zones corresponding land use types: Zone I (agroforest land use zone), LansiumArtocarpus-Swietenia-Ficus-Nephelium-Mangifera zone; Zone II (forest land use zone), Cyathea-Astronia-Syzygium-Garcinia-FicusPsydrax-Diplodiscus zone; and Zone III (forest land use zone), Agathis-Suli-Alitugba-Ardisia zone. Canonical correspondence analysis (CCA) indicated that elevation, temperature and $\mathrm{pH}$ level are the environmental variables that strongly influenced the vegetation distribution in various land uses, a characteristic that is similar to other tropical mountains.
\end{abstract}

Keywords: Canonical Correspondence Analysis (CCA), cluster analysis, dominance analysis, Halcon Range, Mt. Ilong

\section{INTRODUCTION}

Studying the structure of vegetation in tropical mountain areas has been of interest to many scientists, especially to conservationists, because of its fascinating shifts of vegetation along elevational gradients. In Mt. Halcon, a tropical mountain located in Mindoro Island, Philippines, some studies were previously conducted about its vegetation. The oldest and most comprehensive of which were conducted during an exploration study during the early 1900s (Ames 1907; Brotherus 1907; Copeland 1907; Merrill 1907a,b). In a more recent study (Mandia, 1998), the vegetation in the summit zone of Mt. Halcon was explored. These researches have proven the unique biodiversity of the mountain range, thus making it one of the Key Biodiversity Areas of the island (Ambal et al. 2012).

Mt. Ilong is one of the peaks along the Halcon Range. Dutson et al. (1992) provided a description of the forests in Mt. Ilong. The lower edge of the forest begins at $750 \mathrm{~m}$. It was also recorded that there was an intensive pit-saw logging in the area (at 750-850 m), resulting to a severe damage in the forest at that time. The primary forest occurred at $850-1000 \mathrm{~m}$ and above, which is a lowland/mid-mountain transition type, with a canopy reaching at approximately $15 \mathrm{~m}$. It then reaches its plateau at its peak (1,310-1440 m), with a stunted and uneven canopy with needle-leaved trees. Aside from its rich biodiversity, this mountain is part of the ancestral domain of the Alangan Mangyan, one of the indigenous groups living in Mindoro Island.

While it is evident that the flora in Halcon Range is diverse and unique, there is no information on a detailed vegetation distribution and structure along the altitudinal gradient of the Halcon range. Altitudinal zonation studies will be of great help to conservation managers, as these studies provide a more detailed understanding of the vegetation distribution as well as its interplay with the environmental factors.

The vertical structure and distribution of vegetation has been studied in the tropical mountains of the Philippines: in Mt. Pulag (Buot and Okitsu 1998), Mt. Akiki (Buot 2007), Mt. Mayon (Buot 2008), Aborlan Guba System (Sopsop and Buot 2011), Mt. Tabunan (Cadiz and Buot 2011), Mt. Pangasugan (Belonias and Aguilar 2004). These studies emphasize the floristic characteristics of the Philippine tropical mountains, most of which were found to be similar with tropical mountains in the Malesian region (van Steenis 1964, Kitayama 1992, Aiba and Kitayama 1999). In another study in Mt. Makiling, the structure and distribution of vegetation has been applied to observe the land use type patterns (Buot and Osumi 2011). It has been seen in the studies in the Philippine tropical mountains that the anthropogenic disturbance can influence the vegetation distribution and structure, leading to variation in land use types.

This study is an attempt to provide a comprehensive information on vegetation distribution plants in Mt. Ilong, Halcon Range, by analyzing the structure and dynamics of its tree species distribution. Specifically, the study 
identified plant communities along the $100-1,400 \mathrm{~m}$ elevation through cluster analysis. Furthermore, selected environmental variables that influence species distribution were also investigated through canonical correspondence analysis (CCA).

\section{MATERIALS AND METHODS}

\section{Study area}

This study was conducted along the altitudinal gradient of Mt. Ilong, one of the peaks of the Halcon Range with an elevation of approximately 1,440 masl (Dutson et al. 1992). The highest peak in Mindoro Island is Mount Halcon $(2,582 \mathrm{~m})$. It is situated near the middle of the island separating two geopolitical areas, namely the provinces of Oriental and Occidental Mindoro (Figure 1). The foothold of the mountain range is inhabited by the Alangan people, the local people of the area.

Mt. Ilong is part of Barangay Paitan, Municipality of Naujan, Oriental Mindoro, Philippines. Paitan is considered as the little town of the Alangan (Mandia 2004). While the communities in Paitan were described as more acculturated than the other Alangan communities in Mindoro Island, these people have been working as swidden cultivators in the lower slopes; while in the upper slopes towards its peak, they have retained their natural forests. From the higher to the lower elevations of Mt. Ilong, the Alangans obtain various valuable plant resources for their everyday living. Thus, the studying distribution of plants can be a valuable information to both the locals and conservation managers. Moreover, plants can also serve as identifiers of community types across the elevational gradient of Mt. Ilong.

Mindoro Island experiences two weather types under the modified Corona's classification: Type I and Type III. Type I, which is identified on the western side of the island, has two pronounced seasons: dry from November to April and wet for the rest of the year. Type III, which is the climate type on the eastern side, has no pronounced maximum rain period, with a short dry season ranging from one to three months, either during December to February or from March to May.

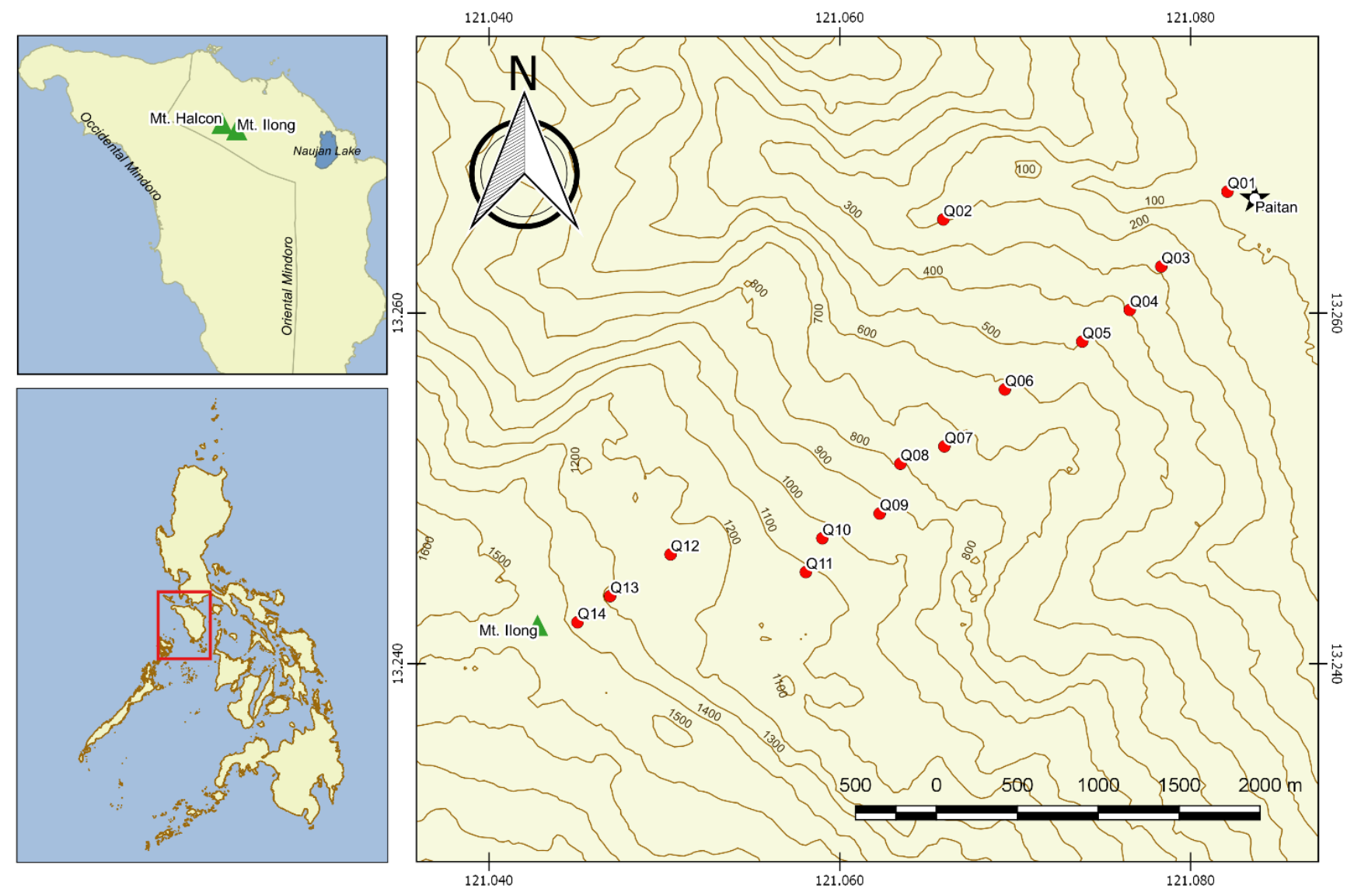

Figure 1. The study area. The Philippine map is shown in the lower left with Mindoro Island emphasized in red box. Photo on the upper left shows a map of Mindoro Island with a more detailed location of Mt. Halcon and Mt. Ilong (marked as $\boldsymbol{\Delta}$ ). The positions of the sampling points are shown on the right, marked as red dots. Maps are generated using QGIS v.2.18.13. 
There is no available meteorological record monitoring specifically for Halcon Range; however, some accounts by previous explorers have emphasized the very high humidity of the mountain, just like in other tropical mountains in the Philippines like Mt. Makiling and Mt. Pulag. Merrill (1907a,b) described Mt. Halcon as probably the most humid mountain in the Philippines, with rains occurring for nine months every year (May to January). Because of this condition, the abundance of ferns, mosses, and epiphytes are very remarkable, especially in the forest zones. The summit zone, on the other hand, has a drier climate having a temperature of around $16{ }^{\circ} \mathrm{C}$, with mostly stunted vegetation interspersed with patches of tall shrubberies and forested areas (Mandia 1999).

\section{Field data collection}

Field data collection was done during the first week of May 2016. The vegetation sampling was conducted along the slopes of Mt. Ilong using quadrat method (Cottam and Curtis 1956). Fourteen sampling plots were established along the slopes of Mt. Ilong, each as a representative of 100-meter altitude (Figure 1). Within each plot, the trees, as well as the associated shrubs and herbs were identified. For tree species, individuals with 1-meter height and above were considered, a quadrat of $10 \mathrm{~m} \times 10 \mathrm{~m}$ starting from 100-meter up to 1400-meter elevation. Within each quadrat, a $2 \mathrm{~m} \times 2 \mathrm{~m}$ area was laid out for shrubs and $1 \mathrm{mx}$ $1 \mathrm{~m}$ for herbaceous vegetation.

Soil samples from the topsoil layer of approximately 30-centimeter depth were also collected from each of the sampling points. The samples were tested for $\mathrm{pH}$, nitrogen, phosphorus and potassium levels using a soil test kit obtained from the Agricultural Systems Cluster, College of Agriculture, University of the Philippines Los Baños.

For each species, the importance value (IV) (Curtis and McIntosh 1951) of each species was calculated as follows:

\section{$I V=$ Relative density + Relative dominance + Relative frequency}

To compute for the relative density, relative dominance and relative frequency, the following formula was used (Mueller-Dombois and Ellenberg 1974): $\square$

$$
\begin{aligned}
& \text { Density }=\frac{\text { Number of individuals of a species }}{\text { Total area of sampling }} \\
& \text { Relative density }=\frac{\text { Density of a species }}{\text { Dentsity of all species }} \times 100 \\
& \text { Frequency }=\frac{\text { Number of plots of which a particular species occurs }}{\text { Total number of plots }} \\
& \text { Relative frequency }=\frac{\text { Frequency of a species }}{\text { Sum frequency of all species }} \times 100 \\
& \text { Belative Basal Area }=\frac{\text { Basal area or cover }}{\text { Total basal area of all species }} \times 100
\end{aligned}
$$

The basal area was derived from the diameter at breast height $(\mathrm{DBH})$ data of the trees using the formula:

$$
B A=\left(\frac{1}{2} d\right)^{2} \times \pi
$$

Where, $\mathrm{d}$ is equal to DBH (at $1.5 \mathrm{~m}$ ). For the herbs and shrubs, the dominance was measured using cover, which is the percent area covered by each species in a quadrat. Instead of relative dominance, the relative cover was used for herbs.

All vascular plants were identified using keys and botanical literature, except for epiphytes and lianas. The nomenclature follows that of Merrill (1923-1926), Pancho (1983), Backer and Bakhuizen v.d Brink (1963-1968), Huang et al. (1993-2003), and Pelser et al. (2011-onwards). The scientific names were also validated through the International Plant Names Index (IPNI 2015).

Voucher specimens of the unidentified plants were deposited at Plant Biodiversity Division Herbarium (PBDH), Institute of Biological Sciences, University of the Philippines Los Baños, Laguna, Philippines. Photographs of these specimens were also deposited at the herbarium.

\section{Cluster analysis}

To identify the major plant communities along the altitudinal gradient of Mt. Ilong, cluster analysis was done using abundance data of the tree species. Bray-Curtis similarity index was calculated from the dataset using Paleontological Statistics (PAST) Software version 3.13 (Hammer 2001). This index is a measure of similarity that is applicable for abundance data (Bray and Curtis 1957). A dendrogram was then constructed using the unweighted pair-group method with arithmetic mean (UPGMA) hierarchical clustering method.

Floristic diversity of each identified zone was also investigated. Shannon-Wiener index, Simpson's diversity index, and Fisher's alpha were all computed and graphed.

\section{Dominance analysis}

The dominance was based on the relative density of each tree species. The number of dominant species for each quadrat and identified zones was determined using the equation of Ohsawa (1984):

$$
d=\frac{1}{N}\left(\sum_{i \in T}\left(x_{i}-\bar{x}\right)^{2}+\sum_{j \in U} x_{j}^{2}\right)
$$

Where, $d$ is the deviation between the actual relative density values and the expected share of corresponding codominant-number model, $N$ is the total number of species, $x_{1}$ is the actual percent share (relative density) of the top species $T, \bar{x}$ is the ideal percent share based on the model, and $x_{j}$ is the percent share of the remaining species $U$.

In this equation, it is assumed that the ideal dominance (the "expected share") of a single species is $100 \%, 50 \%$ if it is shared by two co-dominants, $33.3 \%$ for three codominant, etc. Consequently, the number of dominant species is determined by the one that showed the least deviation value. 


\section{Canonical Correspondence Analysis}

To determine the environmental variables influencing species distribution, canonical correspondence analysis (CCA) (ter Braak 1986) was used. Influences from environmental variables such as elevation, temperature, soil $\mathrm{pH}$, nitrogen, phosphorus, and potassium levels were investigated. From these data, a CCA ordination diagram was created using statistical software $\mathrm{R}$ version 3.4.2 (vegan package) (Oksanen et al. 2007). Temperature at different elevation levels was extracted from the climatic data obtained from the Philippine Atmospheric Geophysical and Astronomical Services Administration (PAGASA), using the assumption of Sarmiento (1986) that there is a corresponding decrease of $0.6^{\circ} \mathrm{C}$ in temperature for every 100-meter elevation rise.

\section{RESULTS AND DISCUSSION}

There were 66 tree species belonging to 37 genera in 27 families (Table 1) that were found from the 14 sampling plots examined along with the gradient of Mt. Ilong. The plant families with the most number of species were Lauraceae (6), Moraceae (4), Myrtaceae (4), and Clusiaceae (3) (Table 1). The tree genera that were recorded with more than one representative species include Ficus, Garcinia, Syzygium, Hopea, and Ardisia.

Figure 2 shows the dendrogram of the 14 sampling sites along the altitudinal gradient of Mt. Ilong, East Halcon Range. At a similarity index of around 0.05 , there was a delineation of each sampling site into three distinct clusters. Zone I was identified as agroecosystem zone, while Zones II and III were identified as forest zones.

\section{Altitudinal zones \\ Zone I: Lansium-Artocarpus-Swienenia-Ficus-Nephelium- Mangifera (agroforest land use)}

The first zone was delineated from the cluster diagram (Figure 2) at a similarity index of around 0.04, which is composed of plots from 100 to $400 \mathrm{~m}$ altitude. This zone was a kaingin (swidden) area maintained by the Alangan people. The vegetation mainly composed of fruit trees such as Lansium parasiticum, Nephelium lappaceum, Mangifera indica, and Cocos nucifera. Aside from tree species, coffee (Coffea robusta) is also planted in this area. Some associated herbs are fern species (Diplazium sp., Nephrolepis sp.), weeds and grasses that are representatives of families Asteraceae, Poaceae, and Cyperaceae (Table 2). The dominant land use in this zone is agroforestry. The maximum diameter at breast height $(\mathrm{DBH})$ recorded in this zone was at $63.0 \mathrm{~cm}$ in the third sampling plot.

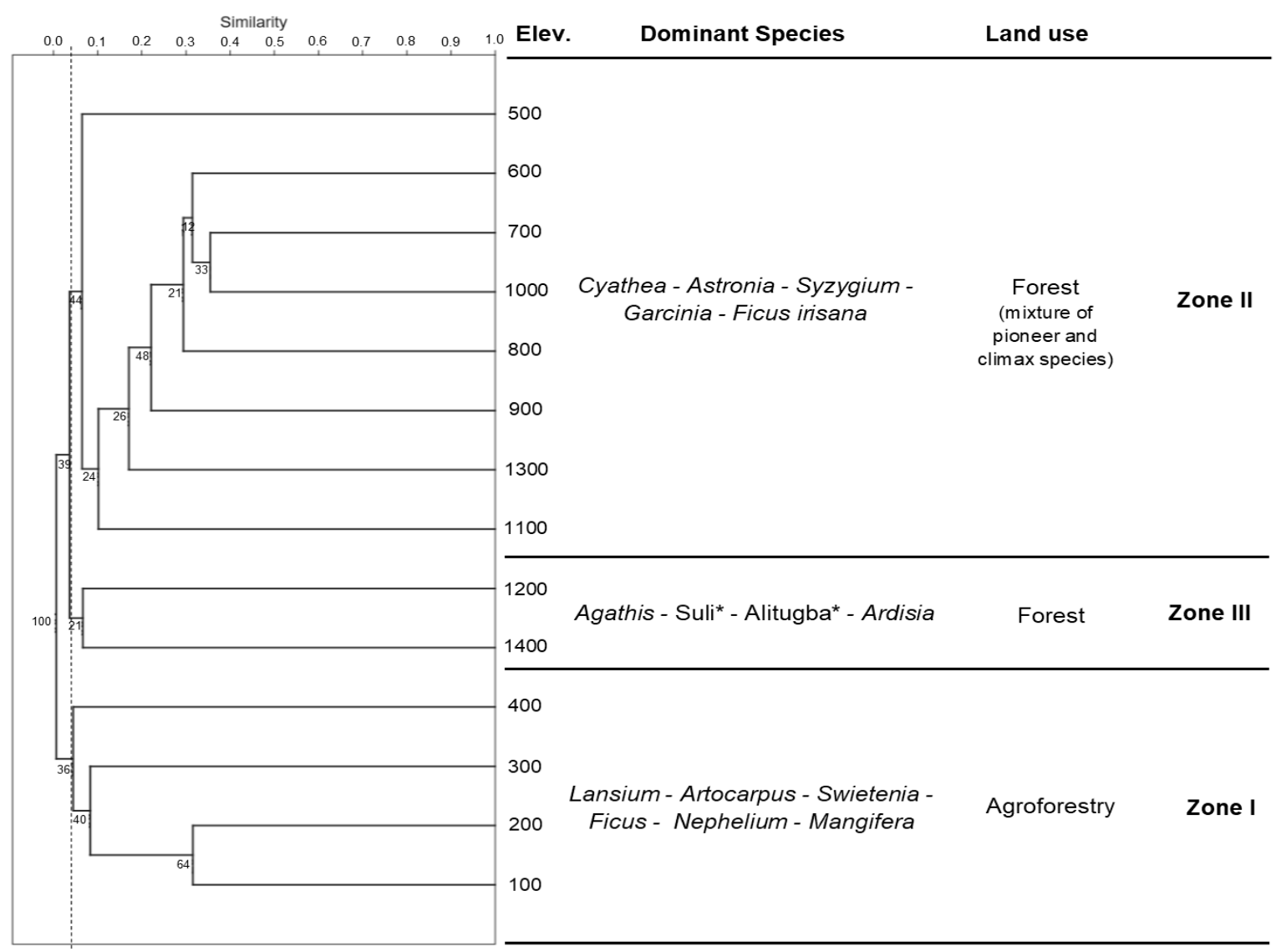

Figure 2. Dendrogram of 14 sampling sites on the altitudinal zones in Mt. Ilong, Halcon Range obtained by UPGMA using Bray-Curtis index of similarity. The elevation of each sampling site and its dominant species are indicated at the right side of the diagram. The zonations identified are as follows: Zone I) Lansium-Artocarpus-Swienenia-Ficus-Nephelium-Mangifera; Zone II) Cyathea-AstroniaSyzygium-Garcinia-Ficus; Zone III) Agathis-Suli*-Ardisia-Alitugba*. Species in asterisk $\left({ }^{*}\right)$ are unidentified, thus written in its local name. Bootstrapping was done at $\mathrm{n}=100$; cophenetic correlation is 0.9268 
Table 1. Tree species composition in the various sampling plots. Relative density $(\mathrm{RD})$ in $\%$ derived from density values. Dominant and co-dominant species are indicated by asterisks $(*)$ and are bordered by a line.

\begin{tabular}{|c|c|c|c|c|c|c|c|c|c|c|c|c|c|c|}
\hline Sampling Site & 1 & 2 & 3 & 4 & 5 & 6 & 7 & 8 & 9 & 10 & 11 & 12 & 13 & 14 \\
\hline Altitude (m) & 69.25 & 197.75 & 293.75 & 399.25 & 492 & 610.75 & 703.25 & 792 & 914.25 & 996 & 1091.5 & 1230 & 1292.75 & 1368.25 \\
\hline Plot size $\left(\mathbf{m}^{2}\right)$ & 100 & 100 & 100 & 100 & 100 & 100 & 100 & 100 & 100 & 100 & 100 & 100 & 100 & 100 \\
\hline Maximum DBH (cm) & 24.8 & 59.8 & 63.0 & 18.5 & 17.8 & 45.5 & 17.2 & 94.5 & 126.7 & 96.1 & 28.7 & 23.6 & 47.8 & 158.5 \\
\hline Name of species [Family] & $\mathrm{RD}$ & $\mathrm{RD}$ & $\mathrm{RD}$ & $\mathrm{RD}$ & $\mathrm{RD}$ & $\mathrm{RD}$ & $\mathrm{RD}$ & $\mathrm{RD}$ & $\mathrm{RD}$ & $\mathrm{RD}$ & $\mathrm{RD}$ & $\mathrm{RD}$ & $\mathrm{RD}$ & $\mathrm{RD}$ \\
\hline $\begin{array}{l}\text { Lansium parasiticum (Osbeck) K.C.Sanhi and Bennet [Meliaceae] } \\
\text { Nephelium lappaceum L. [Sapindaceae] }\end{array}$ & $\begin{array}{l}60.0^{*} \\
20.0^{*}\end{array}$ & $33.3^{*}$ & & & & & & & & & & & & \\
\hline Mangifera indica L. [Anacardiaceae] & 10.0 & & $50.0^{*}$ & & & 8.7 & & & & & & & & \\
\hline & 10.0 & & & & & & & & & & & & & \\
\hline $\begin{array}{l}\text { Swietenia macrophylla [Meliaceae] } \\
\text { Ficus } \mathrm{sp} \text {. [Moraceae] }\end{array}$ & & $33.3^{*}$ & & & & & & & & & & & & \\
\hline $\begin{array}{l}\text { Ficus sp. [Moraceae] } \\
\text { Artocarpus heterophyllus Lam [Moraceae] }\end{array}$ & & $22.2^{*}$ & & & & & & & & & & & & \\
\hline $\begin{array}{l}\text { Artocarpus heterophyllus Lam [Moraceae] } \\
\text { Citrus x microcarpa Bunge [Rutaceae] }\end{array}$ & & 11.1 & $50.0^{*}$ & $66.7^{*}$ & & & & & & & & & & \\
\hline Psydrax dicoccos Gaertn. [Rubiaceae] & & & & 16.7 & & $34.8^{*}$ & 3.1 & & & & & & & \\
\hline Cratoxylum sumatranum (Jack) Blume [Hypericaceae] & & & & & $54.54 *$ & & & & & & & & & \\
\hline Saurauia mindorensis Merr. [Actinidiaceae] & & & & & $18.2^{*}$ & & & & & & & & & \\
\hline Cyathea contaminans [Cyatheaeceae] & & & & & 9.1 & $26.1^{*}$ & $12.5^{*}$ & $25.0^{*}$ & $15.1^{*}$ & $13.3^{*}$ & $13.0^{*}$ & & 6.7 & \\
\hline Litsea sp. [aylanglang] [Lauraceae] & & & & & & $13.0^{*}$ & 3.1 & & & 3.3 & & & $13.3^{*}$ & \\
\hline Ficus ampelas Burm.fil. [Moraceae] & & & & & & & & & & & $43.5^{*}$ & & & \\
\hline Hopea malibato Foxw. [Dipterocarpaceae] & & & & & & & & & & & $21.7^{*}$ & & & \\
\hline Astronia sp. [Melastomataceae] & & & & & & 8.7 & $15.6^{*}$ & 4.2 & $20.8^{*}$ & $6.7 *$ & & & 6.7 & 8.3 \\
\hline Diplodiscus paniculatus Turcz. [Malvaceae] & & & & & & & $15.6^{*}$ & & & $6.7^{*}$ & & & & \\
\hline Syzygium gigantifolium (Merr.) Merr. [Myrtaceae] & & & & & & 4.3 & $15.6^{*}$ & & $20.8^{*}$ & 3.3 & & & & \\
\hline Actinodaphne sp. [Lauraceae] & & & & & & & $6.25^{*}$ & & & & & & & \\
\hline Phoebe sterculoides Merr. [Lauraceae] & & & & & & & & 4.2 & & $10.0^{*}$ & & & & \\
\hline Syzygium sp. [Myrtaceae] & & & & & & & & & 1.9 & & & & 6.7 & \\
\hline Mallotus cumingii Müll.Arg. [Euphorbiaceae] & & & & & & & & & & $16.7^{*}$ & & & & \\
\hline Syzygium sp. [Myrtaceae] & & & & & & & & & & $13.3^{*}$ & & & 6.7 & \\
\hline Ardisia sp. [Primulaceae] & & & & & & & 3.1 & $20.8^{*}$ & & & & & & \\
\hline Garcinia sp. [Clusiaceae] & & & & & & & 3.1 & $16.7^{*}$ & $32.1 *$ & & & & 6.7 & \\
\hline Xanthophyllum bracteatum Chodat [Polygalaceae] & & & & & & & 3.1 & & & & & & & 8.3 \\
\hline Adinandra elliptica C.B.Rob. [Pentaphylaceae] & & & & & & & & $8.3^{*}$ & & & & & 6.7 & \\
\hline Agathis philippinensis Warb. [Araucariaceae] & & & & & & & & & & & & $50.0^{*}$ & & \\
\hline Ardisia sp. [Primulaceae] & & & & & & & & & & & & $16.7^{*}$ & & \\
\hline Macaranga bicolor Müll.Arg. [Euphorbiaceae] & & & & 16.7 & & & & & & & & & & \\
\hline Macaranga sp. [Euphorbiaceae] & & & & & 9.1 & & & & & & & & 6.7 & \\
\hline Garcinia sp. [Clusiaceae] & & & & & & & & & & 3.3 & & & $13.3^{*}$ & \\
\hline T17 & & & & & & & & & & & & & & $25.0^{*}$ \\
\hline $\mathrm{T} 18$ & & & & & & & & & & & & 5.6 & $13.3^{*}$ & $25.0^{*}$ \\
\hline
\end{tabular}


Dacrycarpus imbricatus (Blume) De Laub. [Podocarpaceae]

T15

119

Ficus sp. [Moraceae]

Medinilla magnifica Lindl.

Garcinia binucao (Blanco) Choisy [Clusiaceae]

Barringtonia acutangula subsp. acutangula (L.) Spreng. [Lecythidaceae]

Cyrtandra oblongata [Gesneriaceae]

T63

T65

T35

Cryptocarya sp. [Lauraceae]

Terminalia microcarpa Decne. [Combretaceae]

Buchanania arborescens (Blume) Blume [Anacardiaceae]

Schefflera elliptica Harms [Araliaceae]

Evodia sp. [Rutaceae]

T45
T47

Barringtonia racemosa Spreng [Lecythidaceae]

Cinnamomum mercadoi S.Vidal [Lauraceae]

Actinodaphne multiflora Benth. [Lauraceae]

Tristaniopsis decorticata (Merr.) Peter G. Wilson and J.T.Waterh. [Myrtaceae]

Adonidia merrillii (Becc.) Becc. [Arecaceae]

Hopea plagata S.Vidal [Dipterocarpaceae] 
Zone II: Cyathea-Astronia-Syzygium-Garcinia-Ficus irisana (forest land use)

At around a similarity index of 0.05 , the two forest zones were further defined from the dendrogram. The first forest zone delineated was Zone II, which is a huge cluster from $500-1,100 \mathrm{~m}$ and $1,300 \mathrm{~m}$ elevation. This zone had a lot of co-dominant species (15) based on the dominance analysis. This zone is a mossy forest that was composed of a mixture of pioneer and climax species. Tree ferns (Cyathea contaminans) were frequently occurring among all the plots in this zone. Also, the tree trunks and branches in this zone were mostly colonized with mosses, which can be attributed to its very humid environment. Because this zone is primarily dominated by trees, there were only a few plots in this zone which were found out to have plants of smaller habits (Table 3). Shrubs were found to be present at 500,600 , and $800 \mathrm{~m}$, while herbs were found at 500 and $900 \mathrm{~m}$. Zone II. The top three species with the highest DBH were Garcinia sp. $(94.54 \mathrm{~cm})$, Syzygium sp. $(126.69 \mathrm{~cm})$, and barang $(96.1 \mathrm{~cm})$.

\section{Zone III: Agathis-Suli-Ardisia-Alitugba (forest zone)}

The last identified zone was a mossy forest represented by two sampling points, at $1,200 \mathrm{~m}$ and $1,400 \mathrm{~m}$. Some gymnosperms thrive in high-altitude zone such as Dacrycarpus imbricatus and Agathis philippinensis. Other identified trees found in this zone were Ardisia sp., Astronia sp., Xanthophyllum bracteatum, Tristaniopsis decorticata, and Adonidia merrillii. Shrubs and herbs were only found at a sampling point at 1,400 and are shown in Table 4. The highest DBH among all tree species in this study was recorded in this zone, which is exhibited by a lone species of $D$. imbricatus $(158.5 \mathrm{~cm})$. Other tree species with the highest DBH include $X$. bracteatum $(20.7 \mathrm{~cm})$, alitugba $(26.4 \mathrm{~cm})$ and $A$. philippinensis $(23.6 \mathrm{~cm})$.

\section{Structural characteristics of the forest zones}

The changes in the floristic characteristics in each sampling plot is illustrated in Figure 3. The graphs show the changes in the measures of diversity (number of species, Shannon-Wiener Diversity Index, Simpson Index, and Fisher's Alpha) across an increasing elevation gradient. It was observed that the diversity of agroforestry zone (Zone I) is lower than that of the forest zones (Zones II and III). The usual situation in tropical mountains is that the lower elevations contain the higher diversity than in the higher altitudes; however, this is not the case in Mt. Ilong, which had a lower diversity in the lower altitudes. This is a characteristic shared by other tropical mountains in the Philippines (Buot and Okitsu 1998, Buot 2007, Buot 2008, Buot and Osumi, 2011).

Table 2. Associated shrubs and herbs in Zone I: Lansium-Artocarpus-Swienenia-Ficus-Nephelium-Mangifera (agroecosystem zone)

\begin{tabular}{|c|c|c|c|c|c|c|}
\hline Local name & Scientific name & Family & RD & RF & RDo & IV* \\
\hline \multicolumn{7}{|l|}{ Shrubs } \\
\hline kape & Coffea canephora Pierre ex A.Froehner & Rubiaceae & 25.00 & 33.33 & 25.00 & 83.33 \\
\hline saransok & Melastoma polyanthum Burm.f. & Melastomataceae & 58.33 & 33.33 & 62.50 & 154.17 \\
\hline balitongtong & Clerodendron macrostegium Schauer & Lamiaceae & 16.67 & 33.33 & 12.50 & 62.50 \\
\hline \multicolumn{7}{|l|}{ Herbs } \\
\hline pako (paku-pakuan) & Diplazium sp. & Athyriaceae & 9.76 & 9.09 & 15.38 & 34.23 \\
\hline kulapi & Axonopus compressus (Sw.) P.Beauv. & Poaceae & 15.45 & 18.18 & 7.69 & 41.32 \\
\hline Unidentified & Unidentified & Unidentified & 2.44 & 9.09 & 12.92 & 24.45 \\
\hline uting & Mikania cordata (Burm.f.) B.L.Rob & Asteraceae & 0.81 & 9.09 & 7.08 & 16.98 \\
\hline Unidentified & Cyperus sp. & Cyperaceae & 24.39 & 9.09 & 9.23 & 42.71 \\
\hline dulangan & Pollia secundiflora (Blume) Bakh. f. & Commelinaceae & 2.44 & 9.09 & 1.54 & 13.07 \\
\hline laplapi & Unidentified & Poaceae & 28.46 & 9.09 & 23.08 & 60.62 \\
\hline itos & Pteris sp. & Pteridaceae & 4.07 & 9.09 & 7.69 & 20.85 \\
\hline habu-habu & Elephantopus tomentosus L. & Asteraceae & 2.44 & 9.09 & 6.15 & 17.68 \\
\hline baybalu & Nephrolepis sp. & Nephrolepidaceae & 9.76 & 9.09 & 9.23 & 28.08 \\
\hline
\end{tabular}

Note: $* \mathrm{RD}=$ relative density, $\mathrm{RF}=$ relative frequency, $\mathrm{RDo}=$ Relative dominance, and $\mathrm{IV}=$ Importance Value

Table 3. Associated shrubs and herbs in Zone II: Cyathea-Astronia-Syzygium-Garcinia-Ficus irisana (agroecosystem zone).

\begin{tabular}{|c|c|c|c|c|c|c|}
\hline Local name & Scientific name & Family & RD & $\mathbf{R F}$ & RDo & IV* \\
\hline \multicolumn{7}{|l|}{ Shrubs } \\
\hline uyason & Freycinetia sp. & Pandanaceae & 12.5 & 25 & 32.79 & 70.29 \\
\hline tibanwa & Dracaena angustifolia (Medik.) Roxb. & Asparagaceae & 12.5 & 25 & 8.20 & 45.70 \\
\hline pulbabuyon & Mussaenda philippica A.Rich & Rubiaceae & 75 & 50 & 59.02 & 184.02 \\
\hline \multicolumn{7}{|l|}{ Herbs } \\
\hline pako (paku-pakuan) & Diplazium sp. & Athryriaceae & 20.00 & 25.00 & 21.43 & 66.43 \\
\hline arantoy & Hydrangea chinensis Maxim. & Hydrangeaceae & 40.00 & 25.00 & 14.29 & 79.29 \\
\hline urat & Carex filicina Nees & Cyperaceae & 20.00 & 25.00 & 35.71 & 80.71 \\
\hline alangniwang & Begonia sp. & Begoniaceae & 20.00 & 25.00 & 28.57 & 73.57 \\
\hline
\end{tabular}

Note: $* \mathrm{RD}=$ relative density, $\mathrm{RF}=$ relative frequency, $\mathrm{RDo}=$ Relative dominance, and $\mathrm{IV}=$ Importance Value 
Table 4. Associated shrub and herbs in Zone V: Agathis-Suli-Ardisia-Alitugba (forest zone).

\begin{tabular}{lllllll}
\hline Local name & Scientific name & Family & RD & RF & RDo & IV* \\
\hline Shrubs & & & & & \\
$\quad$ balais & Leea sp. & Leeaceae & 65.00 & 50.00 & 66.67 & 181.67 \\
$\quad$ uyason & Freycinetia sp. & Pandanaceae & 35.00 & 50.00 & 33.33 & 118.33 \\
& & & & & \\
Herbs & & & & & \\
arantoy & Hydrangea chinensis Maxim. & Hydrangeaceae & 64.71 & 50.00 & 21.05 & 135.76 \\
itos & Pteris sp. & Pteridaceae & 35.29 & 50.00 & 78.95 & 164.24 \\
\hline
\end{tabular}

Note: $* \mathrm{RD}=$ relative density, $\mathrm{RF}=$ relative frequency, $\mathrm{RDo}=$ Relative dominance, and IV $=$ Importance Value
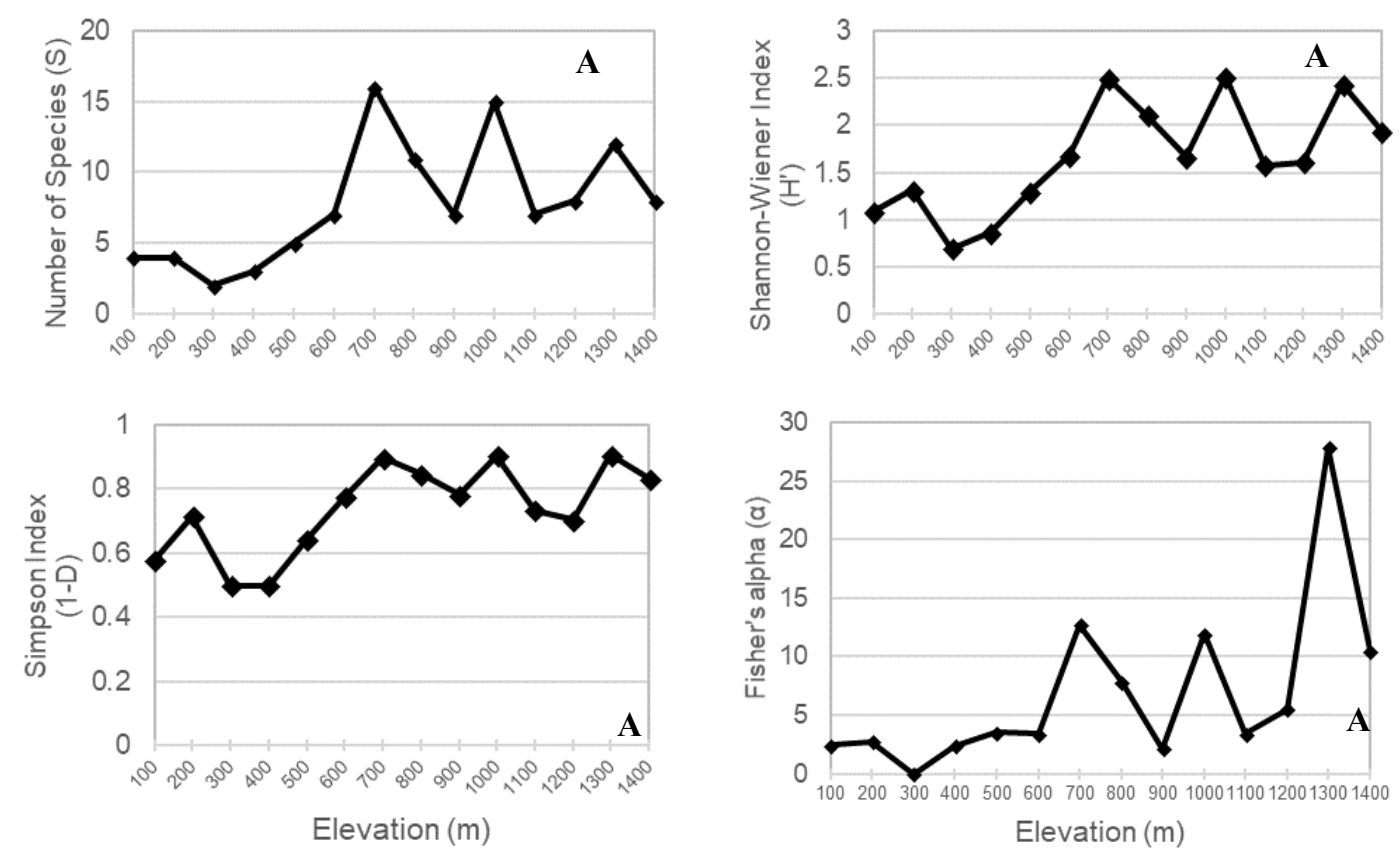

Figure 3. Structural characteristics of the five identified zones of Mt. Ilong, Halcon Range, Philippines. A. Number of species S, B) Shannon-Wiener Diversity Index H, C) Simpson Index 1-D, and D) and Fisher's alpha, $\alpha$

Table 5. Environmental variables of the plots grouped according to identified zones in the cluster analysis

\begin{tabular}{lllllll}
\hline \multirow{2}{*}{ Zone } & \multirow{2}{*}{ Plot } & \multirow{2}{*}{ Elevation } & \multicolumn{4}{c}{ Soil properties } \\
& & & $\mathbf{p H}$ & $\mathbf{N}$ & $\mathbf{P}$ & $\mathbf{K}$ \\
\hline \multirow{4}{*}{ I } & 1 & 69.25 & 6.4 & High & Low & Sufficient \\
& 2 & 205 & 6.8 & High & High & Deficient \\
& 3 & 293.75 & 6 & High & Low & Deficient \\
& 4 & 399.25 & 6 & High & Low & Sufficient \\
& 5 & 492 & 6 & High & Low & Sufficient \\
& 6 & 610.75 & 6 & Medium & Low & Sufficient \\
& 7 & 703.25 & 5.8 & Low & Low & Deficient \\
II & 8 & 792 & 6 & Medium & Low & Sufficient \\
& 9 & 914.25 & 6 & Medium & Low & Sufficient \\
& 10 & 996 & 6 & Low & Low & Sufficient \\
& 11 & 1091.5 & 5.8 & Low & Low & Deficient \\
& 13 & 1230 & 6 & High & Low & Sufficient \\
III & 12 & 1292.75 & 6 & Low & Low & Sufficient \\
& 14 & 1368.25 & 6 & High & Low & Sufficient \\
\hline
\end{tabular}

\section{Relationship of the environmental variables to vegetation distribution in land use types}

The environmental variables that were used in canonical correspondence analysis (CCA) include elevation, temperature, soil $\mathrm{pH}$, nitrogen, phosphorus, and potassium levels. The list of environmental variables recorded per sampling plot is recorded in Table 5.

Using the assumption of Sarmiento (1986) on the temperature changes across altitudinal gradients in tropical mountains, the temperature data for each sampling plot used in CCA was extrapolated from the average 30-year data in Calapan City, Oriental Mindoro, the nearest weather station from Mt. Ilong. The climogram (Figure 4) shows that there is no pronounced dry season in Oriental Mindoro, with the least rainfall recorded within the first quarter of the year. The lowest average rainfall was recorded during the months of February (70.0mm) and March $(93.8 \mathrm{~mm})$. The temperature, on the other hand, ranges from 25.9 to $28.7^{\circ} \mathrm{C}$. 


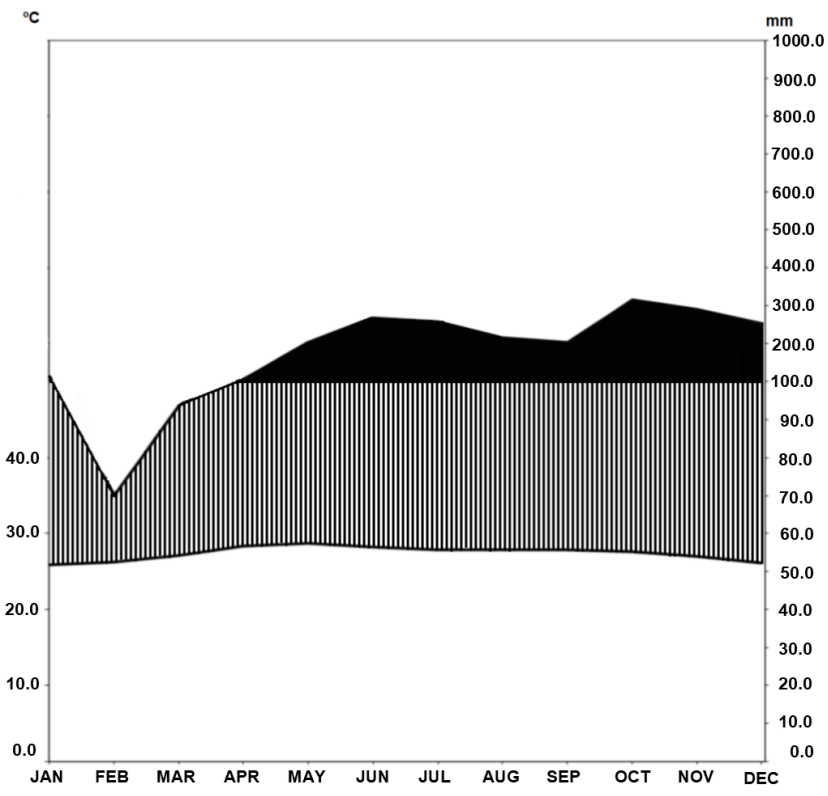

Figure 4. Climogram (average of 30 years for temperature and rainfall data) of Calapan City, Oriental Mindoro, the nearest weather station to the study area

The CCA ordination diagram (Figure 5) was generated to show how the tree species were distributed along the selected environmental variables. The biplot, in general, is consistent with the clustering formed in the dendrogram (Figure 2). The encircled sampling plots (marked as •) in Figure 5a were the three vegetation zones corresponding to land uses identified in the cluster analysis.

A remarkable pattern among the distribution of tree species is that species of Zone I are positioned at the left side of the biplot while tree species of the forest zones (Zones II and III) are situated on the right side of the biplot (Figure 5b). Among the five given variables, the elevation and temperature are found out to be the most important variables that affected the species distribution, as most of the species were plotted near these environmental variables. Moreover, the environmental arrows representing the soil properties are also oriented towards the left side of the diagram, indicating that the soil properties have affected the distribution of trees from the agroecosystem zone (Zone I).

\section{Discussion}

\section{Vegetation structure and land use types}

This study delineated three zones based from the cluster analysis of the abundance data of the tree species (Figure 2). These zones were reflective of the current land use types across the altitudinal gradient of Mt. Ilong. Zone I can be identified as agroforestry zones, which were mostly made up of cultivated fruit trees that cater the needs of the Alangan people, the inhabitants on the lower slopes of Mt. Ilong. Zones II and III, on the other hand, were identified as forest zones made up of a mixture of pioneer and climax species and had a lot of co-dominants. $\square$

Generally, the lower montane forests in Southeast Asia are mainly composed of dipterocarps or an 'oak-laurel' assemblage (Ashton 2003). This pattern was observed at least in some mountains in the Philippines, like the oaklaurel forest in Mt. Pulag (Buot and Okitsu 1999) and the dipterocarp forest of Mt. Makiling (Buot and Osumi 2011). In Mt. Ilong, several trees from Family Lauraceae such as Litsea, Actinodaphne, Phoebe, Cinnamomum, and Cryptocarya were found in the two forest zones (Zones II and III). A few dipterocarps were also identified, belonging to genus Hopea (Table 1).

Another striking observation in the tree composition of Mt. Ilong is the dominance of tree ferns (Cyathea contaminans) in most of the plots, especially in Zone II, the largest cluster in the dendrogram (Figure 2). Cyathea is known to play a prominent role in lower mountain forest areas (Richter 2008), as these species tend to thrive in an environment with high humidity (Banaticla and Buot 2005; Delos Angeles and Buot 2015). Tree ferns are common inhabitants of tropical montane cloud forests (Penafiel 1989). The humid climate prevalent in Mt. Ilong (Figure 5) is conducive for these tree ferns, as well as for the mosses, to grow. Meanwhile, towards the high-altitude Zone III, presence of southern conifers such as Agathis and Dacrycarpus was observed (Table 1). These trees were known to be thriving in mountain areas of higher elevations in the Malesian region (Enright and Jaffré 2010).

The usual trend in the diversity patterns of plant species in tropical mountains is that the number of species, genera, and families and tree assemblages decreases with increasing elevation (Aiba and Kitayama 1999, Kitayama 1992); however, this trend is not observable in some of the tropical mountains in the Philippines, such as in Mt. Pulag (Buot and Okitsu 1998), Mt. Mayon (Buot 2008), and Mt. Makiling (Buot and Osumi 2011). Similarly, in Mt. Ilong (Figure 3), this was also the case, wherein the lower elevations generally exhibited lower diversity than in the plots of higher elevations. Anthropogenic disturbances have played a role in modifying vegetation in tropical forests of the Philippines (Sopsop and Buot 2013), leading to observable changes in land use along elevational gradients in most of the mountains in the country. In Mt. Ilong, the vegetation composition in the lower elevations is being limited by the agroforestry practices. This is evidenced by the presence of fruit trees mostly dominating in the Zone I (Table 1), such as lanzones (Lansium parasiticum), rambutan (Nephelium lappaceum), mangga (Mangifera indica), and niyog (Cocos nucifera).

\section{Species-environment interaction}

The results in the ordination analysis (Figure 5) showed that the elevation and temperature are the major environmental variables that have contributed to the tree species distribution in Mt. Ilong. Altitude is known to be the greatest influencing factor in the changes in floristic composition and diversity in tropical mountains (Hemp 2006), including the mountains in Southeast Asian region (Kitayama 1992, Van and Cochard 2017, Nguyen et al. 2015) and in the Philippines (Buot and Okitsu 1998, Buot 2007, 2008). The composition of the tree assemblages is determined primarily by elevation and the associated environmental gradients such as temperature (Culmsee and 
Leuschner 2013). There is a decreasing temperature trend across an increasing elevation gradient (Sarmiento 1986). This decline in temperature affects the respiratory processes of trees, as well as organic matter storage and decomposition (Culmsee and Leuschner 2013).

The environmental variables can also have an impact in the presence of dominant species in a tropical forest like in Mt. Ilong. By comparing the dominants of the two forest zones, it was observed that forests in lower elevations (Zone II) had more co-dominants than in higher elevations (Zone III) (Figure 2). A structure having many codominants in the lower formations of tropical forests is natural due to interspecific competition among tree species (Grubb 1977). Culmsee and Leuschner (2013) further explained this characteristic, stating that in lower elevations there is a strong competition among species for light and the presence of a higher number of taxa. However, towards higher elevations, the effect of environmental filtering to the plants species tends to increase, as the decreasing temperature limits productivity and nutrient cycling become increasingly important. Furthermore, taxa sensitive to cold environments become excluded increasingly at higher elevations. This environmental filtering was evidently illustrated in the ordination diagram of sampling plots generated from the results of CCA (Figure 5a). The plots in Zone III were plotted inversely with the soil variables, and the species were different (Table 1) and less diverse (Figure 5).
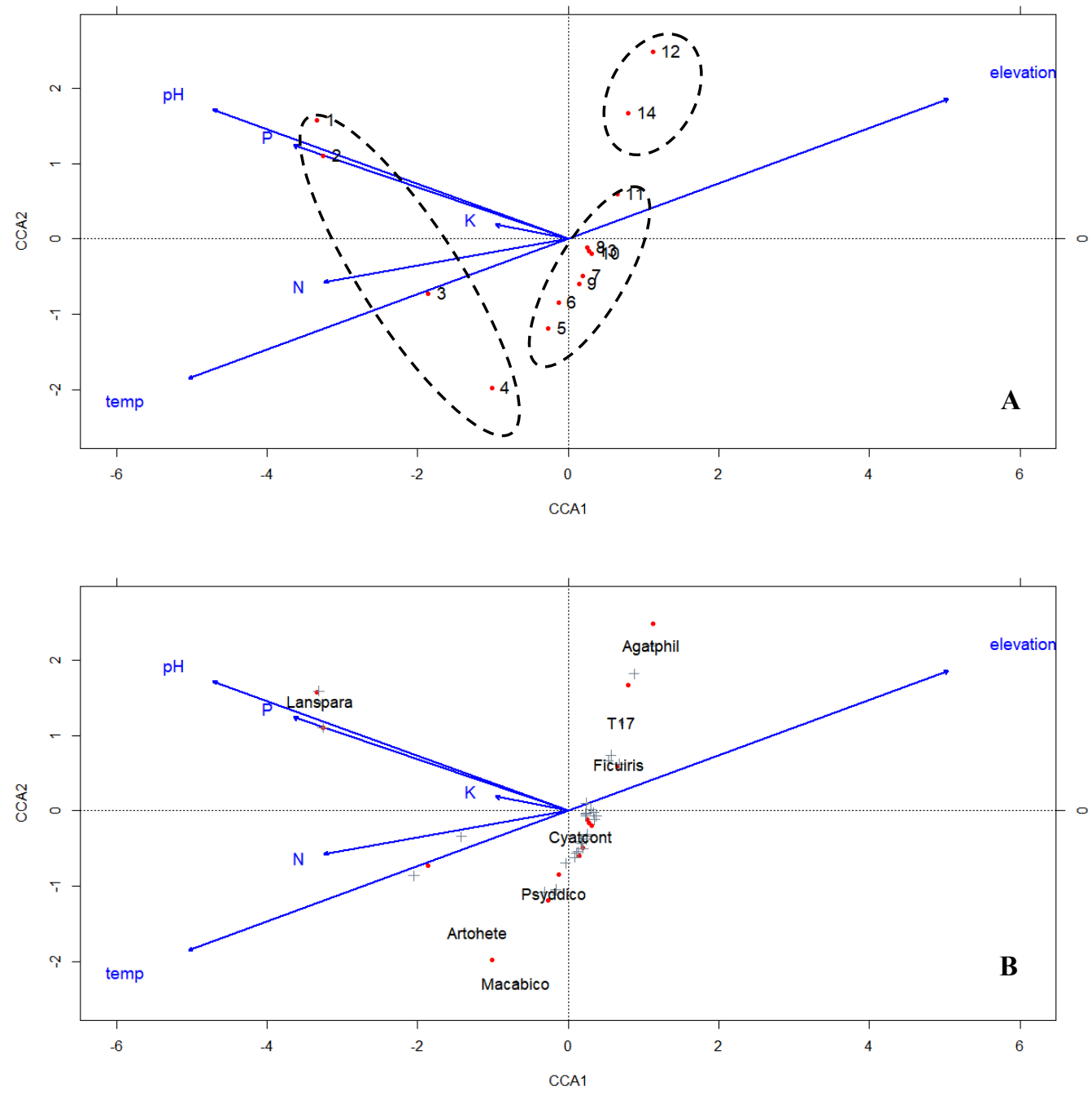

Figure 5. CCA ordination diagrams of tree density data in Mt. Ilong showing [a] sampling plots only (•); and [b] sampling plots and species $(+)$, both of which are positioned with respect to environmental variables (blue arrows). First axis is horizontal; second axis is vertical. The environmental variables are: elevation = mean elevation, temp $=$ temperature, $\mathrm{pH}=$ soil $\mathrm{pH}, \mathrm{N}=$ nitrogen level, $\mathrm{P}=$ phosphorus level, and $\mathrm{K}=$ potassium level. The eigenvalues of axis 1 (CCA1) and axis 2 (CCA2) are 0.9340 and 0.8246 respectively. The eigenvalues of axes 3, 4, 5 and 6 (not shown in the diagram) are $0.6767,0.5787,0.5066$, and 0.3907 respectively. The most abundant species are labeled in this diagram with their abbreviated names: Lanspara $=$ Lansium parasiticum, Citrmicr $=$ Citrufortunellla microcarpa, Artohere = Artocarpus heterophyllus, Mangindi $=$ Mangifera indica, , Macabico $=$ Macaranga bicolor, Psyddico $=$ Psydrax dicoccos, Macasp = Macaranga sp., Cyatcont $=$ Cyathea contaminans, Ardisp $=$ Ardisia sp., Ficuiris $=$ Ficus irisiana , and Agatphil $=$ Agathis philippinensis. The figure shows $21.23 \%$ of the total inertia (weighted variance) and $44.96 \%$ of the variance in the weighted averages and class totals of the species with respect to the environmental variables. 
The soil nutrients can affect the vegetation structure in a tropical forest ecosystem. This has been evident in some studies in the forest formations in the Philippines, where it was also found that soil nutrients (Sopsop and Buot 2013), as well as its water holding capacity (Cadiz and Buot 2011) can affect the vegetation structure. In tropical mountains, soil nutrients such as nitrogen are known to decrease in level while the altitude increases (Aiba and Kitayama 1999 , Kitayama 1992). High plant diversity in low-nutrient soils in the tropical forests is possible because of the soil's ability to limit the domination of the strong plant competitors. This, therefore, allows many species to coexist in an ecosystem (Richter 2008). This characteristic is very much applicable to the two forest zones (II and III), which have many co-dominant species.

The two forest zones (II and III were delineated in the dendrogram (Figure 2) as these two zones have different dominant species, as shown in their tree species composition (Table 1). Zone II, in general, is mostly dominated by tree ferns (Cyathea contaminans), which were absent in Zone III. Gymnosperms such as Agathis and Dacrycarpus, on the other hand, were found in Zone III, which are naturally occurring in high-altitude areas.

In general, in tropical mountain ecosystems, the distribution of tree species is a result of the interaction of multiple environmental factors that limit the species distribution simultaneously (Tanner et al. 2008). Edaphic factors such as soil $\mathrm{pH}$ and nutrient levels, as well as climatic variable like temperature were found to be varying across an altitudinal gradient in Mt. Ilong, which in turn resulted to delineation of specialized the tree communities reflecting different land use types.

In conclusion, contrary to the usual trend in tropical mountains, the structural characteristics of Mt. Ilong were found to be similar with other mountains in the Philippines, wherein the tree species diversity tends to increase along the altitudinal gradient. The vegetation of Mt. Ilong in Halcon Range, Mindoro Island was distributed through a complex interplay of environmental factors. Among the environmental variables examined, elevation, temperature, and $\mathrm{pH}$ have strongly influenced the distribution of tree species in Mt. Ilong, which in turn resulted to specialization of the three identified plant communities reflecting different land use types. Among the three identified zones, Zone I was distinct from Zones II and III as these were mainly agroforestry areas, a land use that is shaped by the Alangan people, the primary users of Mt. Ilong. Towards Zones II and III, the two forest zones, the influence of environmental variables, especially temperature and elevation were evident. These findings on the vegetation distribution along an elevational gradient can be considered as valuable information for the conservation management of Mindoro flora, as well as for the preservation of the culture of the local people.

In future studies, it is recommended to account the effect of human disturbance in the ordination analysis as this has a crucial role in the changes in vegetation structure of tropical mountains such as Mt. Ilong. To improve and update the information on the floral diversity of Halcon Range, further vegetation studies in the other areas of
Halcon Range is also recommended. A higher number of plots to be established will also be helpful in providing a more comprehensive picture of the vegetation structure of the Halcon Range in general.

\section{ACKNOWLEDGEMENTS}

The authors would like to thank the Department of Science and Technology (DOST) for providing funds for this research under the Accelerated Science and Technology Human Resource Development ProgramNational Science Consortium (ASTHRDP-NSC) and the National Research Council of the Philippines (NRCP) MS Thesis Grant; the Mangyan Heritage Center (MHC) and Samahan ng Nagkakaisang Mangyan Alangan (SANAMA) for logistic support and assistance before and during the conduct of the study; and the University of the Philippines Los Baños (UPLB) for providing the authors with facilities and references.

\section{REFERENCES}

Aiba S, Kitayama k. 1999. Structure, composition and species diversity in an altitude-substrate matrix of rainforest tree communities on Mount Kinabalu, Borneo. Plant Ecol 140: 139-157.

Ambal, RGR, Duya MV, Cruz MA, Coroza OG, Vergara SG, De Silva N, Molinyaw N., Tabaranza B. 2012. Key Biodiversity Areas in the Philippines: Priorities for conservation. J Threat Taxa 4 (8): 27882796.

Ames O. 1908. Orchidaceae halconenses: An enumeration of the orchids collected on or near Mount Halcon, chiefly by Elmer D. Merrill. Philipp J Sci 2 (4): 311-337.

Ashton PS. 2003. Floristic composition of tree communities on wet tropical mountains revisited. Perspect Plant Ecol $6(1,2)$ : 87-104.

Backer CA, Bakhuizen, VDB. 1963-1968. Flora of Java, Vol.1-3. P. Noordhoff, Groningen.

Barthlott W, Rafiqpoor D, Kier G., Kreft H. 2005. Global centers of vascular plant diversity. Nova Act Lc 92 (342): 61-83.

Belonias BS, Aguilar NO. 2004. Altitudinal zonation of dicots in Mt. Pangasugan, Leyte Island, Philippines. J Environ Sci Manag 7 (2): 47-66.

Bray JR, Curtis JT. 1957. An ordination of the upland forest communities of Southern Wisconsin. Ecol Monogr 27 (4): 325-349.

Brotherus VF. 1908. Musci Halconenses. Philipp J Sci 2 (4): 339-343.

Buot IEJr. 2008. Vertical distribution and zonation pattern of woody vegetation on the Northwestern Slope of Mt. Mayon, Philippines. Asia Life Sci 17 (2): 189-205.

Buot IEJr, Okitsu S. 1998. Vertical distribution and structure of the tree vegetation in the Montane Forest of Mt. Pulog, Cordillera Mountain Range, the highest mountain in Luzon Is., Philippines. Veg Sci 15: 19-32.

Buot IEJr, Osumi K. 2011. Land use pattern and woody species composition near human-disturbed landscapes on Mount Makiling, Luzon Island. Am J Environ Sci 7 (4): 306-315.

Cadiz GE, Buot IEJr. 2011. Physico-chemical factors affecting the vascular plant diversity of a lowland forest in Mt. Tabunan, Cebu Island, Philippines. Asia Life Sci Suppl 6:1-12.

Cottam G, Curtis JT. 1956. The use of distance measures in phytosociological sampling. Ecology 37 (3): 451-460.

Copeland EB. 1907. Pteridophyta Halconenses: A list of the ferns and fern-allies collected by Elmer D. Merrill on Mount Halcon, Mindoro. Philipp J Sci 2 (4): 119-155.

Culmsee H, Leuschner C. 2013. Consistent patterns of elevational change in tree taxonomic and phylogenetic diversity across Malesian mountain forests. J Biogeogr 40 (10): 14.

Curtis JT, McIntosh RP. 1951. An upland forest continuum in the prairieforest border region of Wisconsin. Ecology 32 (3): 476-496. 
Dutson GCL, Evans TD, Brooks TM, Asane DC, Timmins RJ, Toledo A. 1992. Conservation status of birds on Mindoro, Philippines. Bird Conserv Intl 2: 303-325.

Enright NJ, Jaffré T. 2011. Ecology and distribution of the Malesian podocarps. Sm C Bot 95: 57-78.

Grubb PJ. 1977. Control of forest growth and distribution on wet tropical mountains: With special reference to mineral nutrition. Annu Rev Ecol Syst 8 (1): 83-107.

Hammer Ø, Harper DAT, Ryan PD. 2001. PAST: Paleontologica Statistics Software package for education and data analysis. Palaeontol Electron 4 (1): 9pp

Hemp A. 2006. Continuum or zonation? Altitudinal gradients in the fores vegetation of Mt. Kilimanjaro. Plant Ecol 184: 27-42.

Huang TC, Boufford DE, Hsieh CF, Ohashi H. 1993-2003. Flora of Taiwan. Vol.1-6. The editorial committee of the flora of Taiwan, Taipei.

International Plant Names Index. 2015. www.ipni.org/index

Kitayama K. 1992. An altitudinal transect study of the vegetation on Mount Kinabalu, Borneo. Vegetatio 102 (2): 149-171.

Mandia EH. 1998. The vegetation on the northeastern summit of Mt. Halcon, Mindoro Island, Philippines. [Dissertation]. University of the Philippines Los Baños, Laguna. [Philippines]

Mandia EH. 2004. The Alangan Mangyan of Mt. Halcon, Oriental Mindoro: Their ethnobotany. Philipp Q Cult Soc 32: 96-117.

Merrill, ED. 1923-1926. An Enumeration of Philippine Flowering Plants. Vol. 1-4. Bureau of Printing, Manila

Merrill ED. 1907a. The flora of Mt. Halcon. Philipp J Sci 2c (4): 251-309.

Merrill ED. 1907b. The ascent of Mt. Halcon, Mindoro. Philipp J Sci 2 a (3): 179-205

Morioka H, Sison RV. 1987. Birds of the highlands of Mt. Halcon, Mindoro, Philippines. Jpn J Ornithol 35: 109-124.

Mueller-Dombois D, Ellenberg H. 1974. Aims and Methods of Vegetation Ecology. John Wiley and Sons, USA.

Myers N. 1988. Threatened biotas: "Hot spots" in tropical forests Environmentalist 8 (3): 187-208.

Myers N, Mittermeier RA, Mittermeier CG, Fonesca GAB, Kent J. 2000 Biodiversity hotspots for conservation priorities. Nature 403 (24) $853-858$
Nouyen TV, Mitlöhner R, Bich NV. 2015. Environmental factors affecting the abundance and presence of tree species in a tropical lowland limestone and non-limestone forest in Ben En National Park, Vietnam. J For Environ Sci 31 (3): 177-191.

Ohsawa M. 1984. Differentiation of vegetation zones and species strategies in the subalpine region of Mt. Fuji. Vegetatio 57: 15-82.

Oksanen J, Kindt R, Legendre P, et al. 2007. The vegan package. Community Ecology Package 10: 631-637.

Pancho JV., 1983. Vascular flora of Mount Makiling and Vicinity (Luzon, Philippines). 1st Edn., New Mercury Printing Press, Quezon City, Philippines.

Pelser PB, Barcelona JF, Nickrent DL. (eds). 2011-onwards. Co's Digital Flora of the Philippines. www.philippineplants.org.

Penafiel SR. 1995. The biological and hydrological values of the mossy forests in the Central Cordillera Mountains, Philippines. In: Hamilton LS, Juvik JO and Scatena, FN (eds). Tropical Montane Cloud Forests. Springer, New York.

Richter M. 2008. tropical mountain forests-Distribution and general features. In: Gradstein SR, Homeier J, Gansert D. (eds). The Tropical Mountain Forest-Patterns and Processes in a Biodiversity Hotspot. Universitätsverlag Göttingen, Germany.

Sarmiento G. 1986. Ecologically crucial features of climate in high tropical mountains. In Vuilleumier F and Monasterio M. (eds): High Altitude Tropical Biogeography. Oxford University Press, Oxford.

Sopsop LB, Buot IEJr. 2013. The forest types in Aborlan Guba System, Palawan Island, Philippines. IAMURE Int J Ecol Conserv 7: 88-104.

Tanner EVJ, Vitousek PA, Cuevas E. 1998. Experimental investigation of nutrient limitation of forest growth on wet tropical mountains. Ecology 79 (1): 10-22.

Ter Braak CJF. 1986. Canonical correspondence analysis: A new eigenvector technique for multivariate direct gradient analysis. Ecology 67 (5): 1167-1179.

Van YT, Cochard R. 2017. Tree species diversity and utilities in a contracting lowland hillside rainforest fragment in Central Vietnam. For Ecosyst 4 (1): 9. 